\title{
Factors Influencing Crowdfunding Plausibility in Post Hyperinflationary Zimbabwe
}

\author{
Watson Munyanyi \\ BBS, MBA, Great Zimbabwe University \\ P.O.Box 1235 Masvingo, Zimbabwe \\ Email:wmunyanyi@hotmail.com \\ Alexander Mapfumo \\ DPhil , Great Zimbabwe University \\ P.O. Box 1235, Masvingo, Zimbabwe
}

Received: March 31, 2016 Accepted: May 02, 2016 Published: June 22, 2016

doi:10.5296/jebi.v3i1.9244 URL: http://dx.doi.org/10.5296/jebi.v3i1.9244

\begin{abstract}
In many developing economies access to traditional entrepreneurial financing like banks and venture capitalists has remained suppressed. This has forced many entrepreneurs to resort to non traditional methods of venture financing among them, financial bootstrapping and micro loans. One alternative that these ventures could employ is crowdfunding. Although crowdfunding has remained predominantly a developed world phenomenon, there have been strides in the emerging economies to employ it as an entrepreneurial financing alternative. This paper sought to investigate the factors that are driving the possibility of Zimbabwean entrepreneurs employing crowdfunding as a financing technique. Through survey data collection techniques and statistical data analysis this research managed to highlight the factors in the crowdfunding ecosystem that makes the Zimbabwean economy ready for crowdfunding activities. In line with existing literature five factors were uncovered as the major drivers that make crowdfunding possible in Zimbabwe and the results are used to infer to other emerging economies with similar characteristics.
\end{abstract}

Keywords: Crowdfunding, Entrepreneurship, Entrepreneurial finance, Crowdfunding ecosystem 


\section{Introduction}

Access to entrepreneurial finances from traditional and institutional sources like commercial banks, micro finance institutions and venture capitalist, has remained a challenge in the Sub Saharan Africa. Only a 30\% of the small firms in the Sub Saharan African countries have access to affordable and proper financial capital (World Bank, 2005). Lack of collateral requirements, low income problems in filing tax repayments reports and unsound business plans are some of the reasons for unwillingness of the formal banks lending credit to the majority of entrepreneurs who own micro and small enterprises (Sacerdoti, 2005). Despite the challenges that small to medium enterprises face the role of finance remains critical in the development of entrepreneurship (Olukayode and Sanoye, 2013). The potential of the small to medium enterprises sector across the Sub Saharan Africa remains stemmed in a situation described as the 'missing middle' as the economies suffer from a lack of a roust middle sized enterprises sector (UNDP, 2008). In Zimbabwe although the economy is showing signs of recovery, capital markets and the financial system still remain underdeveloped. They have failed over the decades to provide the much needed financing to entrepreneurial ventures.

With unemployment levels generally high and industry capacity utilization low, starting small businesses, usually informal entrepreneurial ventures have proven to be a viable option for many Zimbabweans. According to Njaya (2014) the informal sector assumed greater prominence through its absorption of retrenching the unemployed tertiary college graduates ad school leavers and as a source of livelihood. By 2013 the small to medium enterprise sector in Zimbabwe was already employing more than $60 \%$ of the country's workforce and contributing about 50\% of the country's Gross Domestic product (MoF, 2013). Simpson et al (2010) noted that the introduction of the multicurrency system (often termed dollarization) and the accompanying stabilization of the economy as well as the trade liberalization of 2008 -2009 have impacted positively (and also negatively) on the development of small to medium enterprises.

One financing alternative that has been employed by entrepreneurial ventures in funding startups and growth is crowd funding. Existing literature cites the 2008 Global Financial Crisis as one of the catalysts to interest in crowdfunding. InfoDev (2013) states that this new form of capital formation emerged in an organized way in the wake of the 2008 Global Financial Crisis largely because of the difficulties faced by artisans, entrepreneurs and early stage enterprises in raising funds. Empirical evidence from developed economies like the United States (Mollick, 2012, Taylor 2015) Netherlands (Song and van Boeschoten, 2014), and Italy (Giudici et al, 2013) show that crowdfunding is a useful tool in bridging the financing gap. According to InfoDev (2013) credible crowdfunding system require more than entrepreneurs and willing investors but also a supportive ecosystem and enabling factors including forward thinking regulators.

Empirical studies have revealed that financing is a greater obstacle for SMEs than it is for large firms, particularly in the developing world, and that access to finance adversely affect the growth of the SME sector more than that of large companies (Schiffer and Weder, 2001; 


\section{Macrothink}

Beck et al, 2005). In Zimbabwe the financial situation for startups and how they finance their ventures has changed over the years and has remained a challenge. Traditional forms of entrepreneurial financing, like bank loans, business angels and venture capitalists have not been applicable to Zimbabwean entrepreneurs in recent years. It is in this context that this research seeks to investigate the plausibility of entrepreneurs pursuing crowdfunding as an alternative source of entrepreneurial financing. According to Massolution, (2013), crowdfunding has now emerged as a viable, scalable alternative to public and private finance. In addition, research has shown that small ventures are turning to innovative routes of resourcing that largely exclude the support of banks and traditional external equity financing (Malmström, 2012, 27).

According to Zhang (2014) crowdfunding is spreading to emerging market with according to InfoDev (2013) a market potential of up to US\$96 billion a year by 2025 in crowdfunding investments in developing countries. The fundamental question that needs to be answered is "Are developing economies in general and Zimbabwe in particular substantially ready to launch crowdfunding campaigns and platforms? Imperative to this research is to uncover whether the crowdfunding ecosystem exists in the Zimbabwean context. The existence of an encouraging ecosystem will facilitate the launch of crowdfunding platforms in Zimbabwe. The crowdfunding ecosystem developed from review off related literature can be represented diagrammatically as follows;

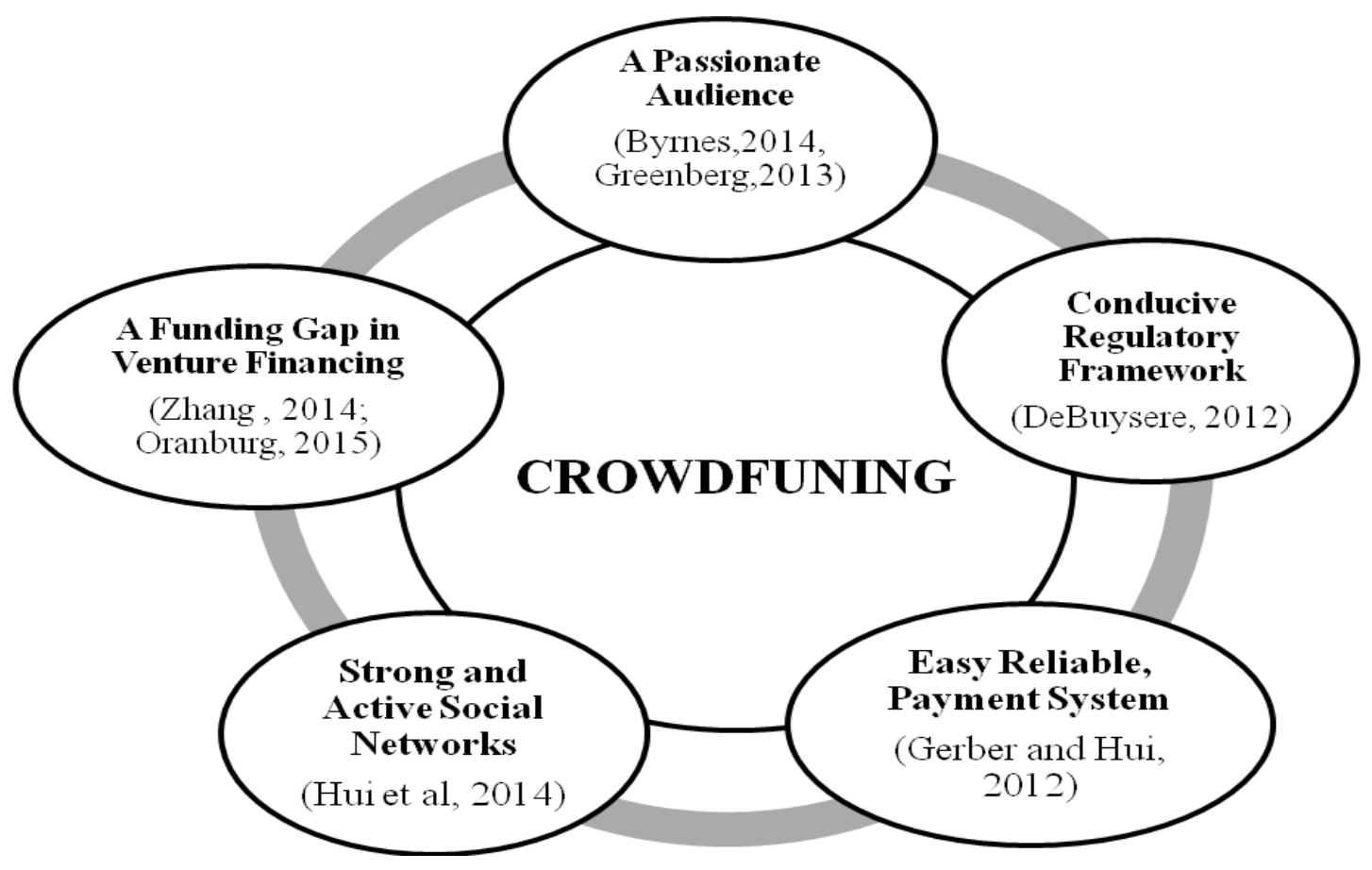

Figure 1. Crowdfuning Ecosystem

Source: Authors' research 


\section{Literature Review}

Throughout the world, shifts in population demographics, technological changes, fluctuating economies and other dynamic forces have transformed societies as never before, bringing new challenges and opportunities to the forefront. Among the responses to these shifting forces is an increased emphasis on entrepreneurship by governments, organizations and the public. (GEM Global Report, 2012). In general, according to Herrington and Kelley (2012) most individuals in Sub Saharan Africa have a high perception about the existence of good opportunities for starting a business in the next six months, with the exception of South Africa (35\%), falling well below the average of $70 \%$ for the region. However, as Fatoki and Chindoga (2011) puts across, the long-term growth and competitiveness of entrepreneurial ventures has been compromised by the chronic and often acute constraints on their access to formal-sector finance, among other systemic and institutional problems in developing countries. Many startup companies cannot access debt finance, since they do not have the needed collateral nor stable cash flows to ensure regular interest payments (Berger and Udell, 1998). According to Ogbor (2009) banks will not lend money for businesses in a saturated or declining industry unless you can convince them that you've got something invested in the business that matters very much to you; what you have invested is your collateral.

Today, technology development costs are plummeting and tools to build software more rapidly and cheaply than ever before and based on the adoption curve of feature phones in Africa are available. Hence, it is possible the $40 \%$ of the people living in Africa will have access to a smart phone within five years (InfoDev, 2013). The development of social networks and the easy access for participants to upload content on websites have contributed to the arising of crowdfunding. Social networks and other online communication tools are particularly suitable for raising awareness of a project as they can reach a large number of people very quickly and spread messages virally amongst online users (DeWit, 2012). More recently, some entrepreneurs have started to rely on the Internet to directly seek financial help from the general public (the "crowd") instead of approaching financial investors such as business angels, banks or venture capital funds (Kleemann et al., 2008; Lambert and Schwienbacher, 2010). This technique, called "crowdfunding", has made possible to seek capital for project-specific investments as well as for starting up new ventures. Lambert and Schwienbacher (2010) describe crowdfunding as "an open call, essentially through the Internet, for the provision of financial resources either in form of donation or in exchange for some form of reward and/or voting rights in order to support initiatives for specific purposes".

Although crowdfunding is still largely a developed world phenomenon, its potential to stimulate innovation and create jobs in developing word has not gone unnoticed (InfoDev, 2013). Adding onto the above notion on crowdfunding InfoDev (2013) states that crowdfunding is an innovation in entrepreneurial finance that can fuel 'the rise of the Rest' globally as substantial reservoirs of entrepreneurial talent, activity and capital lay dormant in many emerging economies, even as traditional attitudes towards risk, entrepreneurship and finance stifle potential economic growth. Crowdfunding is derived from the broader concept of crowdsourcing, the out sourcing of problem solving tasks to a distributed network of 
individuals (Howe 2006; Poetze and Schreier 2012) and draws inspiration from concepts like microfinance (Murdoch, 1999). However, according to Gerber et al (2012) unlike traditional fundraising methods such as applying for funds from banks or foundations, crowdfunding allows creators, people who request resources to appeal for funds directly from supporters, people who give resources through online platforms.

Funding by a large audience differs from traditional funding sources like angel or venture capital investment as it naturally facilitates many small investments rather than a few big ones (Belleflamme et al., 2012). In addition a large audience represents a wide variety of goals (Mollick, 2012) and as a result the relationship between entrepreneur and crowdfunder differs considerably in context and nature of the project. Schwienbacher and Larralde (2010) in agreement with Mollick (2012) concluded it to be a viable source for entrepreneurial seed capital. This is needed because entrepreneurs face the problem to attract outside capital at the early stages of the venture, when lacking cash flow and dealing with information asymmetry with investors (Cosh et al., 2009). Economists have however noted that crowdfunding avoids some of the barriers that can impede offline financial transactions and that crowdfunding can be used by creators to disseminate product information increase customer awareness and estimate customer willingness to pay (Belleflamine et al 2010).

According to Gerber (2012) crowdfunding combines elements of online philanthropic behaviour, online consumer behaviour, online peer to peer lending and online peer production. Online philanthropy is online giving of financial and social capital to promote human welfare. Ordainini et al , (2011) state that crowdfunding platforms serve as 'network orchestrators' because they do not execute specific activities but facilitate those activities by creating the necessary organizational systems and conditions for bringing several players such as campaign owners and investors together. Researchers find that supporters are motivated to give because of sympathy and empathy towards a cause (Rick et al, 2008) ; feelings of guilt for not giving (Cialdini et al 1981) and hopes of strengthening their social identity Aaker and Akutsu, 2009) and social status (Berker, 1974; Glazer and Konrad, 1996).

Although previous literature hints that crowdfunding may be an especially appropriate tool in the start-up phase, the research about its funding growth and expansion potential is in its 'infancy' (Firth, 2012; Lambert, Schwienbacher 2010; Ward, Ramachandran, 2010).

\section{Research Methods}

Arene \& Anyaeji (2010) noted that linear regression analysis may lead to fairly unreasonable estimates when the dependent variable is not singular. Due to the drawbacks of the linear regression models, Gujarati (2003) recommended the use of the logit or probit models. The choice between logit and probit model is, however, difficult to make since they are similar in most applications. Many researchers, however settle for the use of the largest model due to its comparative mathematical, interpretational simplicity and close approximation to the cumulative normal distribution (Hosmer \& Lemeshew, 1989). This paper consequently employed the binary logistic regression model following the footsteps of Arene \& Anyaeji (2010) and Sekhampu (2013). 


\section{Macrothink}

\subsection{Mathematical Representation of the Binary Logistic Regression Model}

The Maximum Likelihood Estimation (MLE) technique was used to estimate the parameter of the logistic regression model. The estimation and specification of binary response function were done using the logistic procedure. Crowdfunding was measured using a bid value of one or zero, where one represents the possibility of crowdfunding and zero represents that crowdfunding was not possible. The logistic regression then provides a model of observing the probability of whether it is possible and viable for crowdfunding to be implemented in Zimbabwe. The binary logistic model adopted from Bogale \& Shimelis (2009) is econometrically specified explicitly as:

$$
P_{i}=F\left(Z_{i}\right)=\frac{1}{1+e^{\left(\alpha+\Sigma \beta_{i} X_{i}\right)}}
$$

Where

$P_{i} \quad$ is the probability of whether it is possible for crowdfunding to be implemented in Zimbabwe,

$X_{i} \quad$ stand in for the $i$ th explanatory variables,

$\alpha$ and $\beta$ are regression parameters to be estimated,

and

e is the base of the natural logarithm

Furthermore, for simplicity and ease of interpretation of the coefficients, a logistic model could be written in the form of the odds and log of odd. The odds ratio is the ratio of the probability that there is a possibility of implementing crowdfunding $\left(\mathrm{P}_{i}\right)$ or there is no possibility to implement crowdfunding $\left(1-P^{i}\right)$. There by yielding;

$$
\left(\frac{P_{i}}{1-P_{i}}\right)=e^{z_{i}}
$$

Taking the natural logarithm of equation (2) yields:

$$
\operatorname{In}\left(\frac{P_{i}}{1-P_{i}}\right)=Z_{i}=\alpha+\beta_{1} X_{1}+\beta_{2} X_{2}+\ldots+\beta_{n} X_{n}
$$


If the disturbance term $U_{i}$ is taken into account, the logit model becomes:

$$
Z_{i}=\alpha+\sum_{i=1}^{n} \beta_{i} X_{i}+U_{i}
$$

Where $\alpha$ and $\beta$ are parameters of the model and can be estimated using the maximum likelihood (ML) method. Where $Z_{i}=$ Crowdfunding (1, if it is possible for crowdfunding; 0 , if it is not possible for crowdfunding) and $\beta_{i}$ is the slope of the equation in the model. The explanatory variables are whether there is a presence of a passionate audience, funding gap in venture financing, strong and active social networks, easy reliable payment system and a conducive regulatory framework.

\section{Results of the Binary Logistic Regression}

Table 1.: Estimated parameters of factors that influence adoption of crowdfunding

\begin{tabular}{|c|c|c|c|c|c|}
\hline Predictor Variables & & $\beta$ & S.E & Wald Statistics & Significance \\
\hline Constant & $\beta_{0}$ & -5.280 & 2.268 & 4.004 & .005 \\
\hline Strong, active social networks & $\beta_{1}$ & 1.653 & .784 & 3.169 & $.063^{*}$ \\
\hline Easy, reliable payment system & $\beta_{2}$ & 1.526 & .895 & 2.906 & $.088^{*}$ \\
\hline A passionate audience & $\beta_{3}$ & 1.610 & .878 & 3.367 & $.067 *$ \\
\hline Conducive regulatory framework & $\beta_{4}$ & .334 & .954 & .123 & .726 \\
\hline A funding gap & $\beta_{5}$ & .165 & .188 & 5.166 & $.018^{* *}$ \\
\hline \multicolumn{6}{|l|}{ (1) Chi-Square $(\mathrm{df}=5)=33.305$} \\
\hline \multicolumn{6}{|c|}{ (2) $(-2)$ Log Likelihood $=11.844$} \\
\hline \multicolumn{6}{|c|}{ (3) Accuracy of prediction; Oppverall $(\%)=82.2$} \\
\hline (4) Nagelkerke $R^{2}=.785$ & & & & & \\
\hline
\end{tabular}
Note: $* * *, * *$ and $*$ indicate significance at $0.01 ; 0.05$ and 0.10 probability level respectively 


\subsection{Interpretation of Econometric Results}

The Hosmer and Lemeshew Goodness-of-Fit test statistic was used to test the model fit and the value of 1.000 was obtained, implying that the model's estimates fit the data at an acceptable level and that there are high chances for the use of crowdfunding in the study area if the challenges being faced are addressed. The Nagelkerke $\mathrm{R}^{2}$ was computed in this study, which was noted by Norusis (2004) to measure proportion of the variation in the response that is explained by the model as a proxy estimate to $\mathrm{R}^{2}$ in OLS regression. Nagelkerke $\mathrm{R}^{2}$ of 0.785 was obtained indicating that more of the variation was explained by the model with an overall prediction percentage of 78.5 as shown in Table 1 above, in this study.

From the research it was shown that all the five predictor variables had positive signs (Strong, active social networks, Easy, reliable payment system, a passionate audience, Conducive regulatory framework and a funding gap). This implies that all the factors have a positive influence on crowdfunding possibility and the existence of these factors in Zimbabwe means that Zimbabwe is ready to employ crowdfunding as a source of entrepreneurial finance.

\section{Discussion}

Strong active social network was found to be an important factor which significantly influences the plausibility of crowdfunding in Zimbabwe. The study revealed that there exists an active and largely strong social networking through the use of social networking platforms like Facebook, Twitter, WhatsApp and LinkedIn in Zimbabwe. The implication of the coefficient is that the probability of financing through crowd funding increases by a factor of 1.653 because of the availability of an active social network. These findings are in line with Museka and Taringa (2014). According to Museka and Taringa (2014) there has been a phenomenal rise in the use of social media networks like Facebook, Twitter, YouTube, WhatsApp, and Skype in Zimawe over the decades especially after the turn of the new millenium. The attribute the incresase in social media usage to the expansion of Internet access through desktop computers, laptops and cell phones.

The variable easy reliable payment system positively influenced the possibility of entrepreneurial ventures employing crowdfunding as a technique to raise capital, with the results obtained using the binary logit regression model in the study area showing a coefficient of 1.526. This indicates that the probability of implementing crowdfunding increases by the factor 1.526 as a result of existing easy payment systems. Payment systems available in Zimbabwe include online banking, telegraphic transfers and the revolutionary mobile money transfer platforms like EcoCash by Econet Wireless Zimbabwe and TeleCash by Telecel Zimbabwe. These findings are in line with Gerber and Hui (2012) who established that the existence of an effective payment system is prerequisite to successful crowdfunding.

A passionate audience is a significant factor in determining the success of crowdfunding initiatives. From the research this variable exhibited a coefficient of 1.610. The implication of the coefficient is that in Zimbabwe there exist an audience, passionate about crowdfunding investments and this makes the crowdfunding ecosystem conducive. This is in agreement with the findings of the study by Byrnes (2014) and also by Greenberg (2013). In order for 
crowdfunding to be a success in Zimbabwe, there is need for potential crowdfunders to be passionate about entrepreneurship in Zimbabwe and be willing to invest in the ventures. The research proves that this exists in the Zimbabwean context, hence a driver of crowdfunding.

On the variables conducive regulatory framework and a funding gap these exhibited coefficients of .334 and .165 respectively. Regulatory framework was established to be insignificant which revealed that it is not conducive for launching crowdfunding. This shows that much needs to be done with regard to the financial regulation in Zimbabwe though the Securities Exchange Commission that governs the operations of capital markets has been in existence since 2008. In addition, because of the liquidity crunch that is bedevilling the Zimbabwean economy since the introduction of the multicurrency system, there is evidence of a funding gap which was also established to be statistically significant at 5 percent in the model.

\section{Conclusion}

In a nutshell the four factors which were obtained to statistically drive crowdfunding are a strong active social network, easy reliable payment system, a passionate audience and a funding gap whilst a lot of work needs to be done to improve the regulatory framework in Zimbabwe. Investors in Zimbabwe are willing to invest in entrepreneurial ventures, there is active and strong use of the social media, there are payment alternatives that can be employed by crowdfunding platforms and there is a funding gap in the economy with regard to entrepreneurial ventures and small to medium enterprises. These factors drive the inevitability of the launch of crowdfunding as a source of entrepreneurial financing in Zimbabwe.

\section{References}

Arene C \& Anyaeji C (2010). Determinants of food security among households in Nsukka Metropolis of Enugu State, Nigeria. Pakistan Journal of Social Sciences, 30(1), 9-16.

Beck, T, Demirgüç-Kunt, A and Maksimovic, V (2005), 'Financial and Legal Constraints to Firm Growth: Does Firm Size Matter?’ Journal of Finance, vol. 60, pp.137-177.

Belleflamme, P., Lambert, T., \& Schwienbacher, A. (2014) Crowdfunding: Tapping the right crowd. Journal of Business Venturing, 29(5): 585---609.

Bogale A \& Shimelis A (2009). Household level determinants of food insecurity in rural areas of Dire Dawa, eastern Ethiopia. African Journal of Food Agriculture Nutrition and Development. Volume 9, Number 9

Fatoki, O. \& Chindoga, L. (2011) An Investigation Into The Obstacles Of Youth entrepreneurship in South Africa. International Business Research, 4(2):161-169.

Giudici, G., Guerini, M. and Lamastra, C.R. (20130 Why Crowdfunding Projects Can Succeed: The Role of Proponents Individual and Territorial Social Capital," SSRN 2255944. 
Gujarati DN (2003). Basic econometrics (Fourth Edition). New York: McGraw-Hill Inc.

Hosmer DW \& Lemeshew S (1989). Applied Logistic Regression. A Wiley-InterScience Publication, New York.

Howe, J. (2006) “The Rise of Crowdsourcing.” Wired Magazine, Issue 14.06.

InfoDev, (2013) Crowdfunding's Potential for the Developing World, Finance and Private Sector Development Department. Washington, DC: World Bank.

International Journal of Entrepreneurial Finance, Volume 16, Issue 1.

Kleemann, Frank, G. Gunter Voss and Kerstin Rieder. (2008) "Un(der)paid Innovators: The Commercial Utilization of Consumer Work through Crowdsourcing." Science, Technology \& Innovation Studies 4:1, 5-26.

Lambert, T, and Schwienbacher, A. (2010) "An Empirical Analysis of Crowdfunding." Available at SSRN: http://ssrn.com/abstract=1578175.

Malmström, M. (2014) Typologies of bootstrap financing behaviour in small ventures. An

Mason, C. (2007) International handbook series on entrepreneurship. In S. Parker (Ed.), The life cycle of entrepreneurial ventures, vol. 3: 259---299 Springer, US.

Massolution (2012) Crowdfunding industry report. http://www.crowdsourcing.org/editorial/total---global---crowdfunding---to---nearlydouble---i n---2012---to---3b---massolution---research---report/14287.

Mollick, E. (2014) The dynamics of crowdfunding: An exploratory study. Journal of Business Venturing, 29(1): 1---16.

Njaya, T. (2014) Exclusion of Informal Sector Enterprises from Banking Services in Zimbabwe: Case of Informal Sector Entrepreneurs in Harare, Global Journal of Advanced Research, Vol-1, Issue-2 PP. 306-314 ,ISSN: 2394-5788 307

Norusis M (2004). SPSS 13.0 Statistical Procedures Companion. Upper Saddle-River, N.J.Prentice Hall, Inc.

Sacerdoti, E. (2005). Access to bank credit in Sub-Saharan Africa: key issues and reform strategies (IMF Working Paper Series, No. WP/05/166). Washington DC: IMF.

Schiffer, M \& Weder, B (2001), 'Firm Size and the Business Environment: Worldwide Survey Results', International Finance Corporation Discussion Paper 43.

Sekhampu TJ (2013). Determination of the factors affecting the Food Security Status of households in Bophelong, South Africa. International Business \& Economics Research Journal - May 2013 Volume 12, Number 5

Song, Y and van Boeschoten R. (2014) Success factors for Crowdfunding founders and funders

Taylor, R. (2015) Equity-based Crowdfunding: Potential Implications for Small Business 


\section{Macrothink}

Capital, Advocacy: the voice of small business in government, Issue Brief Number 5.

Zhang, X. (2014) Co-financing Green Development with Crowds-Exploring the potential of Crowdfunding, A presentation prepared for SWITCH Asia webinar series on Green Financing, Sep.12, 2014,World Bank.

\section{Copyright Disclaimer}

Copyright for this article is retained by the author(s), with first publication rights granted to the journal.

This is an open-access article distributed under the terms and conditions of the Creative Commons Attribution license (http://creativecommons.org/licenses/by/3.0/). 